\title{
Quantitative dynamics of PCB transfer from mother to pup during lactation in UK grey seals Halichoerus grypus
}

\author{
Cathy Debier ${ }^{1}$, Paddy P. Pomeroy ${ }^{3}$, Cédric Dupont ${ }^{4}$, Claude Joiris $^{5}$, \\ Vinciane Comblin ${ }^{4}$, Eric Le Boulengé ${ }^{2}$, Yvan Larondelle ${ }^{1, *}$, Jean-Pierre Thomé ${ }^{4}$ \\ ${ }^{1}$ Unité de Biochimie de la Nutrition (BNUT), and ${ }^{2}$ Unité de Biométrie et analyse des données (BIOM), Université catholique \\ de Louvain, Croix du Sud 2/8 and 2/16, 1348 Louvain-la-Neuve, Belgium \\ ${ }^{3}$ NERC Sea Mammal Research Unit, Gatty Marine Laboratory, University of St Andrews, St Andrews KY16 8LB, Scotland, UK \\ ${ }^{4}$ Laboratoire d'Ecologie animale et d'Ecotoxicologie, Institut de Zoologie, Université de Liège, Quai Van Beneden 22, \\ 4020 Liège, Belgium \\ ${ }^{5}$ Laboratory for Ecotoxicology and Polar Biology, Free University of Brussels, Pleinlaan 2, 1050 Brussels, Belgium
}

\begin{abstract}
PCB contamination was measured in the milk and serum of grey seal Halichoerus grypus mothers and in the serum of their pups sampled from 2 to 5 times between parturition and weaning on the Isle of May, Scotland, in 1998 and 2000. Blubber biopsies were also taken from the lactating females at early and late lactation in 2000. Concentrations of PCBs in milk stayed constant during the first part of lactation $\left(0.31 \pm 0.17 \mu \mathrm{g} \mathrm{g} \mathrm{milk}{ }^{-1}\right)$ and then increased at late lactation $(0.67 \pm 0.42 \mu \mathrm{g}$ $\mathrm{g}$ milk $^{-1}$ ). Curiously, it did not follow the changes of milk lipid content, which increased at early lactation and then stayed constant until the end of the nursing period. As a result, even when expressed per unit of milk lipids, PCBs underwent a rise at the end of lactation. The changes in milk PCBs were accompanied by similar dynamics in maternal serum as well as in pup serum. Increased concentrations of PCBs at late lactation in serum and milk may be explained in part by the changes observed in maternal blubber. PCB levels increased significantly between early and late lactation in inner blubber, suggesting that PCBs are less easily mobilised from blubber than lipids. At late lactation, the retention capacity of the reduced blubber layer for PCBs might have reached its maximum. The mobilization of less polar lipids from blubber might also occur at this stage. In both cases, this could result in a higher mobilization of PCBs at this time. While inner blubber was significantly less concentrated than outer blubber at early lactation $\left(1.26 \pm 0.72 \mu \mathrm{g} \mathrm{g}\right.$ lipids $^{-1}$ in inner blubber vs $3.16 \pm$ $1.34 \mu \mathrm{g} \mathrm{g}$ lipids $^{-1}$ in outer blubber), these variations disappeared at late lactation $(3.24 \pm 2.60 \mu \mathrm{g} \mathrm{g}$ lipids ${ }^{-1}$ in inner blubber vs $3.59 \pm 1.46 \mu \mathrm{g} \mathrm{g}^{-1}$ lipids in outer blubber). Newborn pups already had significantly higher serum levels of PCBs than their mothers, revealing an important placental transfer $\left(11.9 \pm 7.0 \mathrm{ng} \mathrm{ml} \mathrm{serum}{ }^{-1}\right.$ in pups vs $6.7 \pm 3.5 \mathrm{ng} \mathrm{ml} \mathrm{serum}{ }^{-1}$ in mothers $)$. These differences were even greater in late lactation, due to the ingestion of milk $\left(27.9 \pm 18.1 \mathrm{ng} \mathrm{ml} \mathrm{serum}{ }^{-1}\right.$ in pups vs $12.2 \pm$ $7.2 \mathrm{ng} \mathrm{ml} \mathrm{serum}{ }^{-1}$ in mothers). As lactation progressed, PCB levels in pup serum increased exponentially as compared to the levels in the serum of their mothers.
\end{abstract}

KEY WORDS: Grey seal $\cdot$ Halichoerus grypus $\cdot$ PCBs $\cdot$ Lactation $\cdot$ Milk $\cdot$ Serum $\cdot$ Blubber

\section{INTRODUCTION}

The oceans are threatened by human-generated over-fishing, noise and pollution. Persistent organochlorine pollutants such as polychlorinated biphenyls
(PCBs) tend to accumulate up food chains in the marine ecosystems. Ocean and atmospheric currents have distributed these chemicals throughout the biosphere and they are encountered even in remote areas such as the Arctic (Muir et al. 1992). Because they are 
highly lipophilic and resistant to biodegradation, PCBs biomagnify in the fatty tissues of the marine fauna, their concentrations increasing with the trophic level (Tanabe et al. 1981, Muir et al. 1995, Mössner \& Ballschmiter 1997, Bard 1999, Bang et al. 2001). Marine mammals, like seals, are particularly exposed to contamination by PCBs because they are top predators, characterized by relatively long life spans and large deposits of fatty tissue reserves.

Declines of several marine mammal populations, due to virus-related mass mortalities as well as to lowered reproductive success, have been attributed in part to the contamination by PCBs and other organochlorine pollutants (Helle et al. 1976a,b, Martineau et al. 1988, Aguilar \& Borrell 1994, Nakata et al. 1995). Several field and semi-field studies on marine mammals have shown that reproductive failure, immune function impairment, developmental abnormalities, endocrine disruption, carcinogenicity, and vitamin A homeostasis disorders are linked to high concentrations of organochlorine pollutants, and particularly PCBs, in the tissues of the animals (Reijnders 1986, Martineau et al. 1988, Brouwer et al. 1989, Zakharov \& Yablokov 1990, De Swart et al. 1994, Jenssen et al. 1995, Ross et al. 1995, 2000, Beckmen et al. 1997, Bernhoft et al. 2000, Roland 2000, Ross 2000, Simms et al. 2000, Troisi \& Mason 2000).

During lactation, marine mammals transfer high amounts of PCBs from mother to offspring through the milk. This phenomenon leads to a partial detoxification in females. Indeed, they appear to accumulate PCBs in their tissues until they reach sexual maturity. Afterwards, their PCB body burdens remain stable or decline with age due to the transfer of PCBs to offspring during gestation, and particularly during lactation. In contrast, the PCB contamination of males generally increases continuously with age. Levels in adult males thus often exceed those reported in adult females (Tanabe et al. 1994, Kleivane et al. 1995, Nakata et al. 1995, Bernhoft et al. 1997, Westgate et al. 1997, Aguilar et al. 1999, Jepson et al. 1999).

In several seal species, females fast during lactation. Therefore milk constituents as well as the xenobiotics in milk are derived exclusively from maternal body stores. For example, in grey seals Halichoerus grypus, where the milk fat content ranges from 30 to $60 \%$ (Pomeroy et al. 1996), fasting lactating females appear to excrete about $15 \%$ of the PCB body burden during the $18 \mathrm{~d}$ nursing period (Addison \& Brodie 1977). Thus pups ingest a considerable quantity of PCBs through the milk at a time when they are particularly sensitive to any deficiency of essential nutrients, such as vitamin A, for their growth and development, as well as to any dysfunction of their endocrine or immune system. Total exposures of up to $58.9 \mathrm{mg}$ of PCBs for the whole lacta- tion period have been reported in grey seal pups, which could represent a danger during the earliest stage of life (Pomeroy et al. 1996).

Numerous studies have focused on PCB contamination in tissues such as blubber, liver and, to a lesser extent, blood of non-lactating pinnipeds (e.g. Law et al. 1989, Skaare et al. 1990, Nakata et al. 1995, Wolkers et al. 1998, Kleivane et al. 2000, Severinsen et al. 2000). By contrast, reports on concentrations of PCBs in the milk and/or serum of lactating mothers and pups are rare (Green et al. 1996), and often represent single points during lactation or result from the collection of samples from dead animals (Addison \& Brodie 1977, 1987, Bacon et al. 1992, Beckmen et al. 1999). The dynamics of transfer of PCBs from mother to pup over the course of lactation in seals are poorly understood. The present study is the first to describe this process in detail, through longitudinal sampling.

Grey seal mother-pup pairs from the pupping colony of the Isle of May were regularly captured throughout lactation in order to characterize the changes of PCB contamination levels in different compartments (maternal blubber $\rightarrow$ maternal blood $\rightarrow$ milk $\rightarrow$ pup blood). The characteristics of grey seal lactation in the UK (relatively short lactation period, maternal fasting, high lipid transfer from mother to pup) make this species a good model to study the transfer of xenobiotics from mother to pup.

\section{MATERIALS AND METHODS}

Field techniques. The study was conducted on the Isle of May, Scotland (56 $\left.12^{\prime} \mathrm{N}, 2^{\circ} 32^{\prime} \mathrm{W}\right)$, in November 1998 and 2000. A total of 22 mother-pup pairs were captured repeatedly, from 2 to 5 times between birth and weaning, to collect samples at different lactation stages. Blood (mothers and pups) and milk samples were taken in both 1998 and 2000. During the breeding season of 2000, a blubber biopsy extending the full depth of the blubber layer in the dorso-lateral pelvic area was taken from mothers at early and late lactation. Four mothers in 2000 (Seals 6J, 7J, 6L, 41) had also been sampled in 1998. One mother from 2000 (Seal 7J) was sampled before she gave birth. The dates of birth were recorded by observing the breeding areas on each day. In 2 cases (pups of Seals 41 in 1998 and $1 \mathrm{H}$ in 2000), the date of birth could not be reported and was determined using extrapolation (Pomeroy et al. 1999). All animal handling as well as milk and blood collection were carried out as described in Debier et al. (2002) under the UK Home Office licence. The data on mother-pup pairs and number of samples collected are summarized in Table 1. 
Table 1. Halichoerus grypus. Number of samples obtained from the grey seal mother-pup pairs followed during the longitudinal study

\begin{tabular}{|c|c|c|c|c|c|c|}
\hline & $\begin{array}{l}\text { Seal } \\
\text { code } \mathrm{n}\end{array}$ & $\begin{array}{c}\text { Age of } \\
\text { mothers (yr) }\end{array}$ & $\begin{array}{l}\text { Blubber } \\
\text { samples (n) }\end{array}$ & $\begin{array}{c}\text { Mother serum } \\
\text { samples (n) }\end{array}$ & $\begin{array}{c}\text { Milk } \\
\text { samples (n) }\end{array}$ & $\begin{array}{l}\text { Pup serum } \\
\text { samples (n) }\end{array}$ \\
\hline \multirow[t]{9}{*}{1998} & $7 \mathrm{~J}$ & 8 & 0 & 2 & 3 & 2 \\
\hline & $6 \mathrm{~L}$ & $>8$ & 0 & 3 & 5 & 3 \\
\hline & $6 \mathrm{~J}$ & 8 & 0 & 2 & 3 & 2 \\
\hline & 41 & $?$ & 0 & 2 & 4 & 2 \\
\hline & D0 & 21 & 0 & 4 & 4 & 4 \\
\hline & 68 & 8 & 0 & 2 & 3 & 2 \\
\hline & 59 & $?$ & 0 & 3 & 4 & 3 \\
\hline & 46 & $?$ & 0 & 2 & 4 & 2 \\
\hline & 44 & 8 & 0 & 0 & 4 & 0 \\
\hline \multirow[t]{13}{*}{2000} & $7 \mathrm{~J}$ & 10 & 2 & 3 & 3 & 3 \\
\hline & $6 \mathrm{~L}$ & $>10$ & 2 & 3 & 3 & 3 \\
\hline & $6 \mathrm{~J}$ & 10 & 2 & 3 & 3 & 3 \\
\hline & 41 & $?$ & 0 & 2 & 2 & 2 \\
\hline & H7 & 28 & 2 & 0 & 2 & 0 \\
\hline & 51115 & $?$ & 2 & 3 & 3 & 3 \\
\hline & 51113 & $?$ & 2 & 3 & 3 & 3 \\
\hline & $4 \mathrm{~B}$ & 16 & 2 & 2 & 2 & 2 \\
\hline & 418 & $?$ & 2 & 3 & 3 & 3 \\
\hline & $2 B$ & 16 & 2 & 0 & 2 & 0 \\
\hline & $1 \mathrm{H}$ & $?$ & 0 & 0 & 3 & 0 \\
\hline & $\mathrm{OH}$ & $?$ & 2 & 0 & 3 & 0 \\
\hline & D8 & $>20$ & 2 & 0 & 2 & 0 \\
\hline
\end{tabular}

Blubber samples. Blubber biopsies were cut at their inner and outer extremities and $1 \mathrm{~cm}$ of each extremity (inner blubber and outer blubber) was transferred into a test tube. Fat ( $30 \mathrm{mg})$ was then extracted from the tissue by heating it 3 times in a microwave for $20 \mathrm{~s}$ at $650 \mathrm{~W}$.

Serum samples. The sample preparation was set up by adapting a method established by the Laboratory of Food Analysis (University of Liège, Belgium) according to Singh et al. (1998), Janak et al. (1999), Pauwels et al. (1999) and Frenich et al. (2000). Serum was first deproteinised by adding $100 \mu \mathrm{l}$ of triethylamine and $10 \mathrm{ml}$ of formic acid to a precisely known volume of sample (from 2.5 to $10 \mathrm{ml}$, depending on the amount of sample available). The mixture was stabilized for $30 \mathrm{~min}$ in an ultrasound bath (Julabo USR 05). PCBs were then extracted by SPE (solid phase extraction), using a C18 micro-column (Baker). The column was first conditioned with

Chemical analyses. Chemicals: All solvents were of pesticide grade; n-hexane and acetone (Burdick \& Jackson brand) were purchased from Fluka (Buchs, Switzerland). The Mirex (Dodecachloropentacyclo[5.3.0.0.0.0]decane) used as internal standard, the pure PCB congeners (IUPAC nos. 8, 18, 28, 44, 52, 66, 70, 87 , $95,101,105,110,118,128,138,149,153,156,170,180$, $183,187,194,195,206,209)$ and the congener used as surrogate (IUPAC no. 112), were obtained from Ultra Scientific $^{\circledR}$ and Dr Ehrenstorfer ${ }^{\circledR}$. All other chemicals used were of analytical grade.

Sample preparation: Milk samples. Milk samples were thawed and homogenised with an Ultra-Turax (Ika-Werk 18/10 Janke \& Kunfel). A 2 g sample was then lyophilized over $20 \mathrm{~h}$ and dry matter was determined gravimetrically. Milk lipids were extracted using an accelerated solvent extractor (ASE) (Dionex ASE 2000, Dionex Corporation). A 650 to 750 mg sample of lyophilized milk with $0.5 \mathrm{~g}$ of anhydrous sodium sulphate was extracted 3 times with a mixture of hexane, dichloromethane and methanol (5:2:1, v:v:v) at $80^{\circ} \mathrm{C}$ and under a pressure of 1500 Psi. The solvent with the extracted fat was collected in pre-weighed vials and was evaporated at $40^{\circ} \mathrm{C}$ under nitrogen flow (Turbovap LV Zymark). The fat content of milk samples ('hexane-extracted fat') was determined gravimetrically. Lipids were then dissolved into $3 \mathrm{ml}$ of hexane and collected into a test tube. The mixture was homogenized by vortexing during $1 \mathrm{~min}$.
$10 \mathrm{ml}$ of methanol followed by $10 \mathrm{ml}$ of distilled water using a Supelco elution device (Visiprep DL) and a vacuum pump (ABM). The deproteinized sample was then added to the column. After the sample had passed through, the column was rinsed with $3 \mathrm{ml}$ of distilled water and then dried for 20 min using the vacuum pump. The PCBs retained on the column were then eluted with $5 \mathrm{ml}$ of hexane.

Sample clean-up: All prepared samples (milk, blubber and serum) were then purified by acid and Florisil clean-ups. A $2 \mathrm{ml}$ volume of sulphuric acid mixture (fuming sulphuric acid $30 \%$ and concentrated sulphuric acid $95 \%, 1: 3, \mathrm{v}: \mathrm{v})$ was added to the sample and the mixture was homogenized by vortexing before being centrifuged for $3 \mathrm{~min}$ at $1810 \times g$ at $10^{\circ} \mathrm{C}$ (Jouan). The organic phase was transferred to another tube and the acidic phase was extracted with $3 \mathrm{ml}$ of hexane, vortexed and centrifuged for another $3 \mathrm{~min}$. The organic phases were pooled and reduced to $1 \mathrm{ml}$ under a nitrogen flow. The second clean-up was performed with Florisil ${ }^{\circledR}$ solid phase cartridges (Supelco, EnviFlorisil). The cartridges were first conditioned with $5 \mathrm{ml}$ of acetone, $5 \mathrm{ml}$ of an acetone-hexane mixture (50:50, v:v) and $12 \mathrm{ml}$ of hexane, successively. The sample was then added at the top of the column. Polar molecules were retained on the Florisil ${ }^{\circledR}$ (magnesiumsilicate mixture). The test tubes containing the sample were rinsed with $3 \mathrm{ml}$ of hexane and added to the cartridge. Another $3 \mathrm{ml}$ of hexane were finally directly 
added to the column. The eluate was then evaporated just to dryness under a gentle nitrogen flow.

Analysis: The dried residue of milk samples was reconstituted in $500 \mu \mathrm{l}$ of hexane. Two levels of dilution were then realized, leading to theoretical volumes of 1 and $5 \mathrm{ml}$, in order to quantify the least and most concentrated congeners, respectively. Mirex $\left(100 \mathrm{pg} \mathrm{pl}^{-1}\right)$ (Dr Ehrenstorfer ${ }^{\circledR}$ ) was added as an internal standard

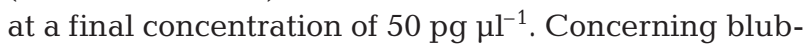
ber and serum samples, the dried residue was reconstituted with $125 \mu \mathrm{l}$ of hexane and $125 \mu \mathrm{l}$ of Mirex $\left(100 \mathrm{pg} \mathrm{pl}^{-1}\right)$.

The purified extracts were then analysed by gas chromatography using a Thermo Quest Trace 2000 gas chromatograph equipped with a ${ }^{63} \mathrm{Ni}$ ECD detector (Thermo Quest, Trace 2000) and an automatic injector. From 1 to $5 \mu \mathrm{l}$ of each purified extract was injected by means of a cold 'on column' injector. PCB congeners were separated on a $30 \mathrm{~m} \times 0.25 \mathrm{~mm}(0.25 \mu \mathrm{m}$ film $) \mathrm{DB}$ XLB capillary column (J\&W Scientific). The temperature program was as follows: 2 min at $60^{\circ} \mathrm{C}$, gradual heating from 60 to $140^{\circ} \mathrm{C}$ at the rate of $20^{\circ} \mathrm{C} \mathrm{min}{ }^{-1}$, 3 min at $140^{\circ} \mathrm{C}$, gradual heating from 140 to $270^{\circ} \mathrm{C}$ at the rate of $25^{\circ} \mathrm{C} \mathrm{min}{ }^{-1}$ and $12 \mathrm{~min}$ at $270^{\circ} \mathrm{C}$. The carrier gas was hydrogen with a flow rate of $4 \mathrm{ml} \mathrm{min}^{-1}$ and a pressure of $130 \mathrm{kPa}$, and the make-up gas was $\mathrm{Ar}: \mathrm{CH}_{4}$ (95:5) at a flow rate of $30 \mathrm{ml} \mathrm{min}{ }^{-1}$. The injector was at ambient temperature and the detector was kept at $300^{\circ} \mathrm{C}$. PCBs were identified according to their retention times. Twenty-six congeners, mostly present in Aroclor 1242, 1254 and 1260 mixtures, were measured (IUPAC 8, 18, 28, 44, 52, 66, 70, 87, 95, 101, 105, $110,118,128,138,149,153,156,170,180,183,187$, 194, 195, 206, 209). Data were recorded using ChromCard 1.19 software. Quantification was performed by comparison with external standards of the 26 pure PCB components in a certified calibration mixture (Ultra Scientific and Dr Ehrenstorfer ${ }^{\circledR}$ ), using a linear calibration curve for each $\mathrm{PCB}$ congener whose concentration

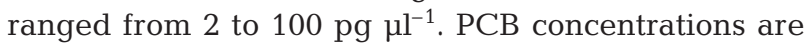
expressed as the sum of the congeners measured.

Quality assurance. Blanks were run with each sample series to control the clean-up procedures. Concerning the milk samples, blanks were also used to control lyophilization and ASE steps. For each type of sample (milk, blubber or serum), a quality control (QC) was also analysed in parallel. Milk cream and bovine serum, enriched with a defined concentration of PCBs, as well as cod liver oil of known PCB concentration (BCR RM 349) were used as a QC for milk, serum and blubber analysis, respectively.

The PCB recovery was calculated on the basis of the concentration of the surrogate standard (IUPAC 112,

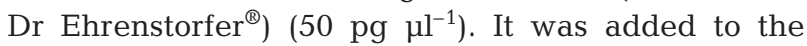
sample at the beginning of the clean-up for blubber and milk samples and at the beginning of the sample preparation for serum samples. All results were corrected to obtain $100 \%$ recovery. However, the results of the PCB analyses were accepted only if the recoveries were between 70 and $130 \%$.

Data analyses. Results were analyzed using the GLM procedure (SAS/STAT 1990).

Blubber samples: Blubber biopsies were taken only at early and late lactation for all females and were divided into 2 layers (inner and outer blubber, see 'Chemical analyses' subsection). PCB concentration variations in the blubber were analyzed using a 3-way mixed ANOVA, crossed design, with the following factors: individual, stage of lactation (early or late), and blubber layer (inner or outer). Stage of lactation and blubber layer were combined into a single 4-level factor, whose levels could then be compared pairwise, using Bonferroni's $t$-test for paired samples.

Milk and serum samples: The variations of $\mathrm{PCB}$ concentrations among individuals and as a function of the age of pups (a continuous regressor variable) were analyzed using a 2-way mixed analysis of covariance (ANCOVA). Both PCB concentrations and their logarithms $\left(\log _{e}\right)$ were analysed, the latter transformation intending to lower the variance heterogeneity observed between early and late lactation. The logarithmic model was chosen.

Milk samples were taken for each female at different stages of lactation. We compared the fit of a quadratic function of the age of pup with that of a linear (first order) model. The model was chosen on the basis of the significance of the quadratic term. Only the linear model was considered in serum samples because there were fewer longitudinal data.

In order to facilitate the presentation of the results, we will refer to 'early lactation' for the period from Day 0 to Day 5 and to 'late lactation' for the period from Day 11 to Day 20.

\section{RESULTS}

\section{Maternal blubber}

PCB levels in blubber layers are presented in Table 2 and Fig. 1. Concentrations showed significant differences between females $(p<0.01, d f=9,27)$. At early lactation, inner blubber was significantly less contaminated than outer blubber $(p<0.01, d f=3,27)$. These differences disappeared at late lactation $(\mathrm{p}>0.05, \mathrm{df}=$ $3,27)$. Concentrations in inner blubber increased significantly between early and late lactation $(\mathrm{p}<0.01$, $\mathrm{df}=3,27$ ). In outer blubber, no significant difference of concentration was noted between early and late lactation ( $p>0.05, \mathrm{df}=3,27)$. 
Table 2. Halichoerus grypus. PCB ( $\mu \mathrm{g} g \mathrm{lipid}^{-1}$ ) concentrations in the inner and outer blubber layers of mothers at early (Days $0-5)$ and late ( $\geq 11 \mathrm{~d}$ ) lactation

\begin{tabular}{|lcccc|}
\hline \multirow{2}{*}{ Seal code } & \multicolumn{2}{c}{ Early lactation } & \multicolumn{2}{c|}{ Late lactation } \\
& Inner & Outer & Inner & Outer \\
\hline 7J & 1.11 & 2.33 & 1.43 & 2.65 \\
6L & 0.86 & 2.28 & 2.48 & 2.83 \\
$6 \mathrm{~J}$ & 0.58 & 2.37 & 1.16 & 2.61 \\
15 & 0.94 & 3.56 & 2.49 & 3.87 \\
13 & 0.93 & 1.52 & 2.39 & 2.71 \\
4B & 2.82 & 5.88 & 10.09 & 6.78 \\
18 & 1.83 & 5.00 & 4.33 & 5.59 \\
OH & 0.73 & 3.00 & 3.93 & 2.77 \\
H7 & 1.99 & 3.10 & 2.31 & 2.53 \\
2B & 0.82 & 2.53 & 1.78 & 3.57 \\
Mean & 1.26 & 3.16 & 3.24 & 3.59 \\
SD & 0.72 & 1.34 & 2.60 & 1.46 \\
& & & & \\
\hline
\end{tabular}

\section{Maternal serum}

In blood, PCBs are mainly associated with proteins and lipoproteins. The lipid fraction of serum is composed of more polar lipids when compared to subcutaneous fat or other organs (Henderson et al. 1994), and contains non-polar lipids (i.e. hexane-extractable fat) at a very low rate. Expressing PCB concentrations in serum on a lipid weight basis (i.e. hexane-extractable fat) would thus lead to an overestimation. As a consequence, and in order to compare the PCB levels in serum with data in the literature, $\mathrm{PCB}$ concentrations were expressed on a per serum volume basis.

PCB concentrations in maternal serum were $6.69 \pm$ $3.45 \mathrm{ng} \mathrm{ml}^{-1}$ and $12.18 \pm 7.15 \mathrm{ng} \mathrm{ml}^{-1}$ at early and late lactation, respectively.

The results of the ANCOVA for PCBs in maternal serum are summarized in Table 3. PCB concentrations differed between individuals, especially at late lacta-

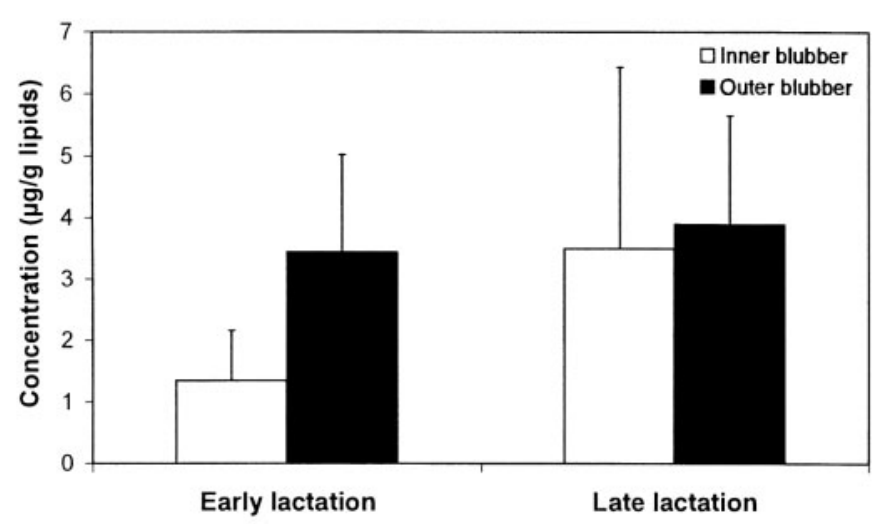

Fig. 1. Halichoerus grypus. PCB contamination in inner and outer blubber layers of lactating mothers at early (Days 0-5) and late $(\geq 11 \mathrm{~d})$ lactation
Table 3. Halichoerus grypus. Effect of time (age of the pup) and mother (individual) on the PCB content in the serum of mothers (ANCOVA)

\begin{tabular}{|lrcrc|}
\hline Source & df & Mean square & F-value & $\mathrm{p}>F$ \\
\hline Age of pup (A) & 1 & 2.23 & 16.86 & 0.0017 \\
Individual (I) & 15 & 0.34 & 2.55 & 0.0611 \\
Interaction I-A & 15 & 0.13 & 1.00 & 0.5104 \\
\hline
\end{tabular}

tion (Fig. 2A). PCB concentrations in maternal serum were higher at late lactation compared to early lactation (Table 3). The magnitude of the increase varied from one individual to the other. It was for example very slight for $6 \mathrm{~J}-00$ and $7 \mathrm{~J}-00$ while for $4 \mathrm{~B}$, concentrations more than doubled between early and late lactation (Fig. 2A).

\section{Milk}

Milk lipid content increased as lactation progressed, from $33.8 \pm 5.0 \%$ in colostrum to $56.3 \pm 6.2 \%$ in milk after Day 12 (Fig. 3) ( $<<0.01$, df $=1,23$ ). There were slight but significant differences in milk lipid content among mothers $(\mathrm{p}=0.02$, $\mathrm{df}=21,23)$.

In whole milk, mean PCB levels were $0.31 \pm 0.17 \mu \mathrm{g}$ $\mathrm{g}^{-1}$ and $0.67 \pm 0.42 \mu \mathrm{g} \mathrm{g}^{-1}$ at early and late lactation, respectively. In milk lipids, mean concentrations were $0.76 \pm 0.43 \mu \mathrm{g} \mathrm{g}^{-1}$ and $1.22 \pm 0.78 \mu \mathrm{g} \mathrm{g}^{-1}$ at early and late lactation, respectively. The levels of PCBs did not follow the same dynamics as lipids in milk (Fig. 3).

The results of the ANCOVA for PCBs in milk are summarized in Table 4. Milk PCB concentrations were very different from one female to another. As in maternal serum, the differences among mothers were greater at late lactation compared to early lactation (Fig. 2B). There was a significant quadratic change in concentration of PCBs in milk throughout lactation (Table 4): levels appeared to stay relatively constant until Day 10 and then underwent an increase towards the end of lactation. As in maternal serum, the increase was not as important in all females. PCB concentrations more than tripled during lactation in Seals 4B and D0, while they increased only slightly in Seals $1 \mathrm{H}$ and H7 (Fig. 2B). These variations were reflected in the covariance analysis (ANCOVA) by the significant interaction between the individual and the time of lactation (Table 4). When PCB concentrations were expressed on a lipid weight basis, their concentrations also appeared to differ between individuals ( $p<0.01$, $\mathrm{df}=21,23$ ) and to increase significantly at the end of lactation $(\mathrm{p}<0.01$, $\mathrm{df}=1,23)$. 

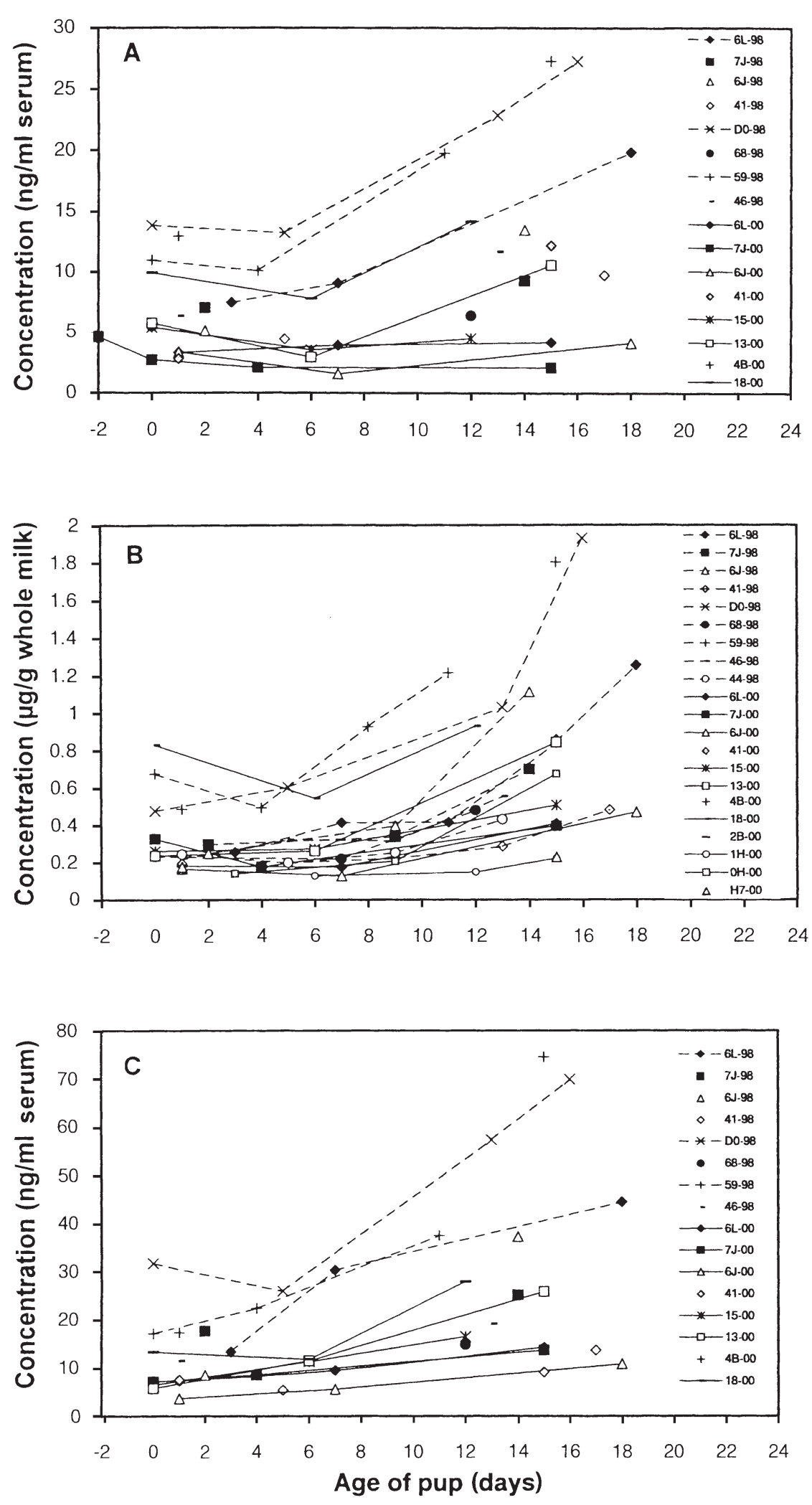

Fig. 2. Halichoerus grypus. PCB contamination of (A) mother serum, (B) milk, and $(\mathrm{C})$ pup serum throughout the lactation period. Dashed lines: pairs from 1998; straight lines: pairs from 2000. Isolated points are from pairs captured twice only.

\section{Pup serum}

Mean PCB levels in pup serum were $11.86 \pm 7.00 \mathrm{ng} \mathrm{ml}^{-1}$ and $27.89 \pm 18.13 \mathrm{ng}$ $\mathrm{ml}^{-1}$ at early and late lactation, respectively.

The results of the ANCOVA of PCB concentrations in pup serum during nursing are shown in Table 5. Contamination levels highly differed from one pup to another and were greater at late lactation compared to early lactation (Fig. 2C). The differences between individuals appeared once again to be more important at late lactation compared to early lactation, and the increase in concentration varied between individuals (Fig. 2C).

\section{Relationships}

Positive correlations were observed between inner blubber and maternal serum ( $r=0.93, p<0.01)$, maternal serum and milk ( $\mathrm{r}=0.92, \mathrm{p}<0.01)$ as well as milk and pup serum $(\mathrm{r}=0.90, \mathrm{p}<$ 0.01). These correlations are the result of comparable changes of concentration occurring in each of the compartments investigated throughout lactation. Fig. 4 illustrates this phenomenon by presenting 2 mother-pup pairs: one showing slight variations with time (Seal 6J-00) and the other showing large variations with time (Seal 4B).

When considering the entire lactation period, contamination levels appeared to be significantly higher in the serum of pups compared to the serum of their mothers $(p<0.01$, df $=1,15)$. The PCB concentration in pup serum as a function of the PCB concentration in mother serum shows an exponential relationship (Fig. 5).

We were unable to show variation in contaminant levels in the blubber, serum and milk of mothers as a function of age. When Seals D0 (21 yr old) and $4 \mathrm{~B}$ (16 yr old) were compared to the 8 to 11 yr group (Seals 6J, 7J and 6L), a positive relationship seemed to appear with the age of the mother. However, Seal H7 (28 yr old) had contamination levels relatively similar to those 


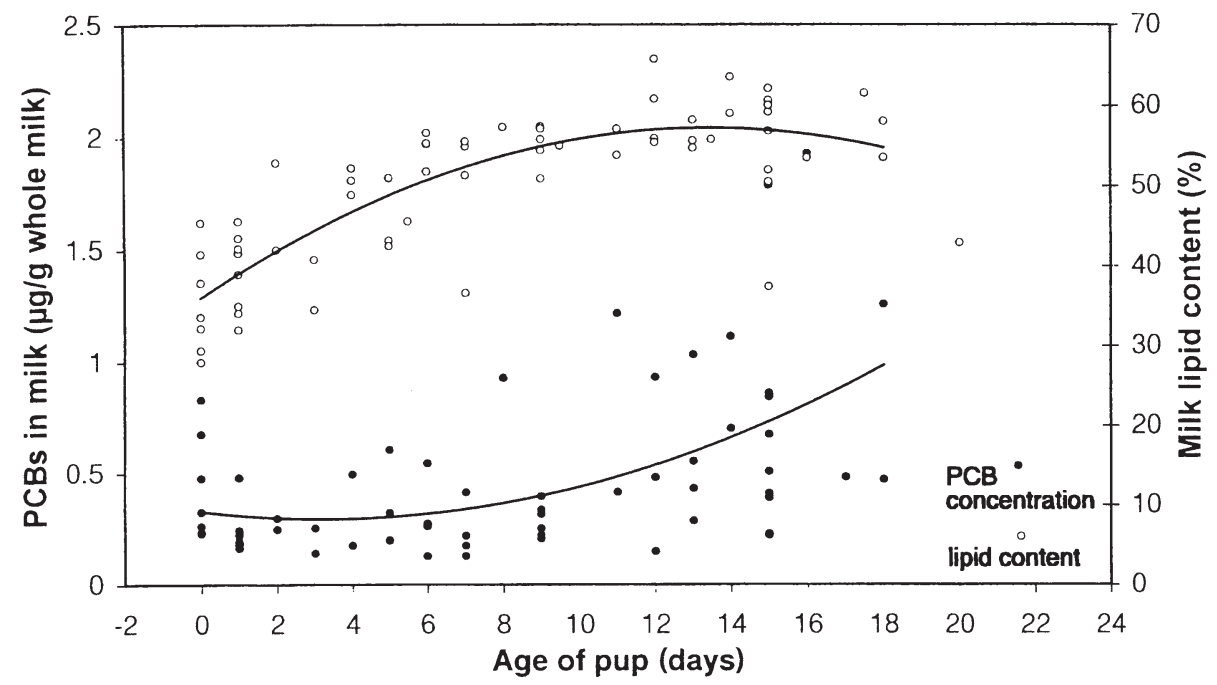

Fig. 3. Halichoerus grypus. Overall changes in PCB contamination as well as lipid content in milk throughout lactation
PCBs and other fat-soluble pollutants from the blubber compartment into the blood and then the milk. These chemicals are known to induce negative effects, like immunotoxicity, reproductive failure and developmental problems in the organisms they contaminate (Helle et al. 1976a,b, Reijnders 1986, Zakharov \& Yablokov 1990, De Swart et al. 1994, Ross et al. 1995). The impact may be particularly deleterious in young animals because they rely on adequate metabolism for their growth, development and immune system, and they have a lower ability to detoxify xenobiotics than adults (Timbrell 1991, Bernhoft et al. 1997). of the younger mothers. Moreover, Seals 4B and 2B (both 16 yr old) showed very different contamination levels.

\section{DISCUSSION}

Grey seals, like several other true seal species, fast during lactation. Milk energy and nutrient contents are thus derived entirely from maternal body stores. The lipids of grey seal milk originate mainly from the blubber. This important lipid transfer from maternal blubber stores inevitably induces the mobilization of

Table 4. Halichoerus grypus. Effect of time (age of the pup) and mother (individual) on the PCB content in the milk (ANCOVA)

\begin{tabular}{|lrccc|}
\hline Source & df & Mean square & F-value & $\mathrm{p}>F$ \\
\hline Age of pup (A) & 1 & 0.33 & 14.54 & 0.0009 \\
Age of pup $^{2}\left(\mathrm{~A}^{2}\right)$ & 1 & 1.50 & 66.2 & 0.0001 \\
Individual (I) & 21 & 0.20 & 8.85 & 0.0001 \\
Interaction I-A & 21 & 0.09 & 3.74 & 0.0014 \\
\hline
\end{tabular}

Table 5. Halichoerus grypus. Effect of time (age of the pup) and pup (individual) on the PCB content in the serum of pups (ANCOVA)

\begin{tabular}{|lrcrr|}
\hline Source & df & Mean square & $F$-value & $\mathrm{p}>F$ \\
\hline Age of pup (A) & 1 & 6.02 & 131.02 & 0.0001 \\
Individual (I) & 15 & 0.40 & 7.36 & 0.0015 \\
Interaction I-A & 15 & 0.07 & 1.52 & 0.2542 \\
\hline
\end{tabular}
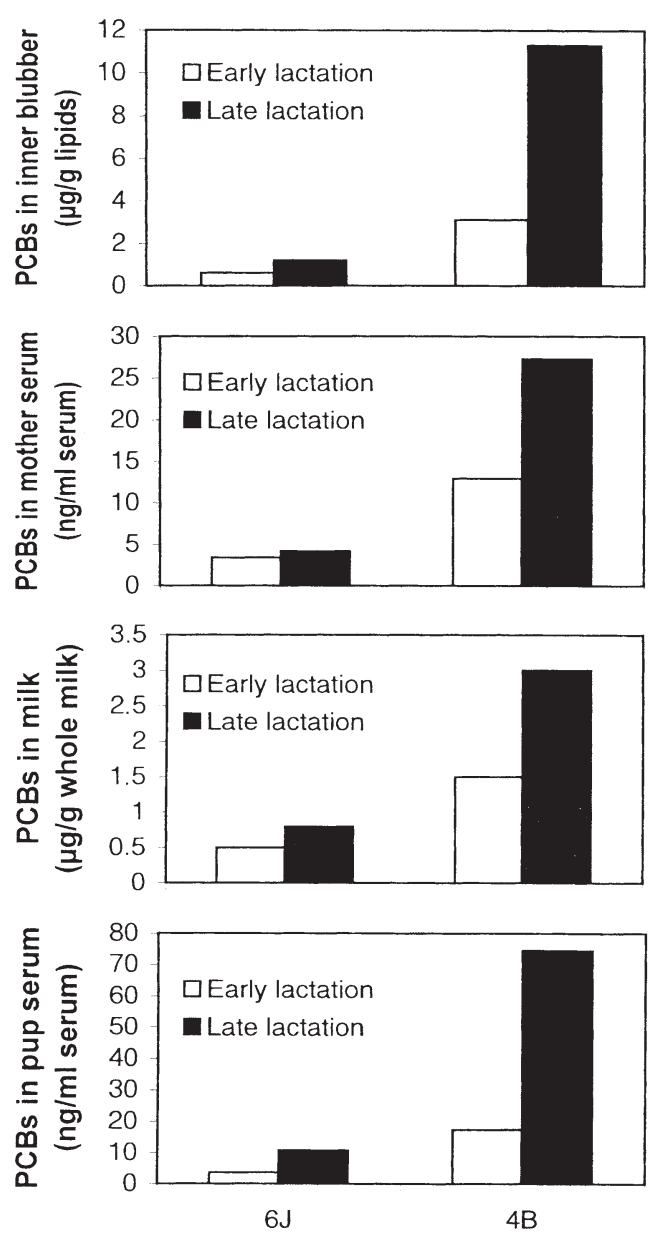

Fig. 4. Halichoerus grypus. Changes in the concentrations of PCBs from one compartment to the other for 2 mother-pup pairs (Seals 6J-00 and 4B) 


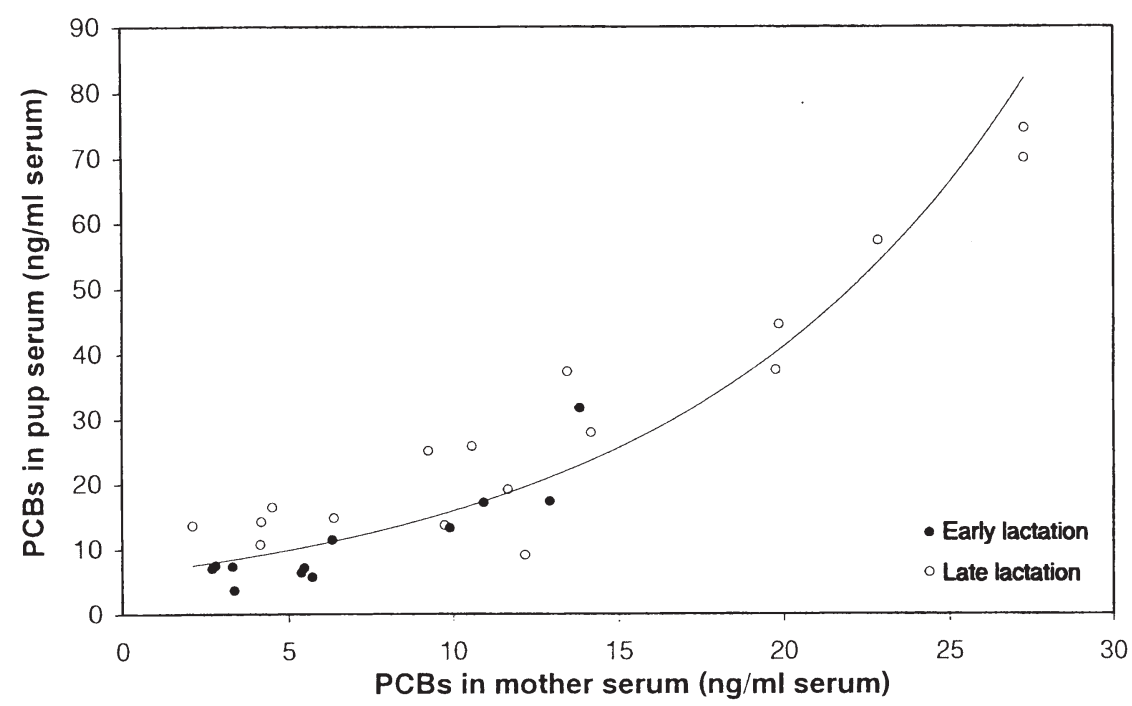

Fig. 5. Halichoerus grypus. PCB contamination in pup serum as a function of maternal serum at early and late lactation

\section{Contamination levels of grey seals during lactation}

At early lactation, inner and outer blubber PCB concentrations within seals were very different, while these variations were much less clear at late lactation. Differences in blubber-layer concentrations have already been noticed by Severinsen et al. (2000) for male and female ringed seals Phoca hispida from Svalbard. Fatty acid composition of the blubber layers was suggested to be one of the causative factors of such differences. The authors pointed out the fact that if the studies reporting $\mathrm{PCB}$ levels in blubber of marine mammals are based on biopsies using sampling tools that only penetrate the outer part of the blubber, the PCB burden is probably overestimated. Indeed, most studies focusing on PCB concentrations in marine mammal blubber do not make the difference between inner and outer blubber or the condition of the animal. Comparisons of contamination within the literature are therefore unlikely to be standardized.

PCB levels observed in the blubber of lactating grey seals from this study were lower than those reported for pinnipeds such as harbour seals Phoca vitulina, Baikal seals P. sibirica, California sea lions Zalophus californianus and grey seals from highly polluted areas (Law et al. 1989, Schweigert \& Stobo 1994, Nakata et al. 1995, Bernt et al. 1999, Kajiwara et al. 2001). Conversely, the blubber concentrations observed in this study were higher than those reported in Arctic species such as the ringed seal (Addison \& Zinck 1986, Cleeman et al. 2000, Severinsen et al. 2000). Concentrations encountered in the blubber of lactating UK grey seals were below the threshold of $17 \mathrm{mg} \mathrm{kg}^{-1}$ at which direct health problems have been reported (Ross et al. 1996).

Few studies report PCB concentrations in the serum and milk of marine mammals. PCB concentrations in the serum of grey seals presented in this study were respectively slightly higher and 1 order of magnitude higher than the levels reported in the serum of ringed seal and bearded seal Erignathus barbatus females from Svalbard (Bang et al. 2001). The levels found in grey seal milk from the present study were lower than the ones reported in grey seal milk from Sable Island (Schweigert \& Stobo 1994). Comparable PCB concentrations were seen in the milk of northern fur seals Callorhinus ursinus from Alaska and in the milk of northern elephant seals Mirounga angustirostris from California, when expressed on a wet weight basis (Bacon et al. 1992, Beckmen et al. 1999). Levels of up to 2 orders of magnitude lower were noticed in the milk of Antarctic fur seals Arctocephalus gazella (Bacon et al. 1992).

The geographic location thus seems to play an important role on the contaminant burden of pinnipeds. However, factors such as the age and sex of the animals, their feeding habits, physiological status (lactating, fasting, ill ...), the blubber layer considered, the total body blubber content, the inter-specific metabolism capacities, as well as the sampling and analytical techniques used might also have an impact on the PCB levels reported in the different surveys (Addison \& Zinck 1986, Skaare et al. 1990, Nakata et al. 1995, Mössner \& Ballschmiter 1997, Wolkers et al. 1998, Bernt et al. 1999, Kleivane et al. 2000, Severinsen et al. 2000, Addison \& Stobo 2001).

PCB concentrations in all compartments (blubber, serum and milk) differed among mothers, consistent with previous observations in grey seal milk from the same colony (Pomeroy et al. 1996). While we did not detect an effect of age on the variation in PCB concentrations in these lactating females, age and reproductive history may nonetheless influence contaminant concentrations. Indeed, gestation and lactation constitute major ways of elimination of PCBs and, in several species, a decrease in the concentrations of PCBs with age has been noticed in the tissues of sexually mature females. By contrast, some studies reported a steady state in the tissue PCB concentrations, the elimination through milk being compensated for by food ingestion (Addison \& Brodie 1977, Nakata et al. 1995, Aguilar et al. 1999, Bernt et al. 1999). The foraging habits and sites used can also be responsible for the inter-individ- 
ual differences of contamination. Indeed, variations in the foraging behaviour of individual grey seals occur in the North Sea (Hammond et al. 1993). Regional and seasonal variations in the diet of grey seals have also been reported (Prime \& Hammond 1990). Other factors such as the reproductive history (females sometimes miss some reproductive years), total blubber amount, as well as temporal trends in the contamination levels of the marine biota would also need to be taken into account to explain patterns of contamination.

The variations of the contamination status in mothers were reflected by varying levels in the serum of the nursing pups. Very young pups had higher serum PCB levels than their respective mothers, revealing an important transplacental transfer as described by Beckmen et al. (1999) for Northern fur seal pups. This phenomenon was greatly amplified during lactation with the ingestion of milk. The higher PCB levels may be in part explained by the higher lipid content in the serum of pups compared to the mothers, reflecting the pup's intense feeding on milk (Addison \& Brodie 1987). Moreover, from a contaminant perspective, nursing pups can be regarded as feeding at a higher trophic level than their mother (Beckmen et al. 1999).

\section{PCB transfer from mother to pup}

In all the successive transfer compartments studied with regard to $\mathrm{PCB}$ transfer (maternal blubber $\rightarrow$ maternal blood $\rightarrow$ milk $\rightarrow$ pup blood), an increase in the concentration of PCBs was noted in the course of lactation. An increase of PCB levels in grey seal milk throughout lactation was also observed by Schweigert \& Stobo (1994) but, as only 2 measures were made, at early and late lactation, the dynamics of this increase could not be reported. In the present study, longitudinal data were able to describe how these changes occurred in milk over the course of lactation, and a curious phenomenon could be observed. It appeared that concentrations stayed relatively stable until Day 10, and then started to increase towards the end of the nursing period. Curiously, this dynamic was not similar to the one observed in the present study for milk lipid content which increased at early lactation and then stayed stable after Day 10. Thus, even when expressed per kg of milk lipids, PCBs underwent a rise at the end of lactation.

The increase in milk lipid PCBs at late lactation is probably because of a mobilization from a more contaminated site during that period. Data reported in blubber may explain this phenomenon. Concentrations in inner blubber, the layer probably the most in contact with the blood circulation, appeared to increase sharply between early and late lactation, while in the outer blubber, PCB content stayed much more stable.
The increase in the inner blubber levels from early to late lactation possibly resulted from the fact that the PCBs are less easily mobilized from blubber than triglycerides, the dominant lipid type (Henderson et al. 1994), and are thus redistributed in the remaining blubber layer which becomes more and more reduced as lactation proceeds. This pathway was part of the hypotheses stated by Aguilar (1985) concerning the destination of pollutants from the blubber, when fat is mobilized from this tissue during fasting. An increase in the concentrations of organochlorine pollutants like PCBs has been documented in harp seals during the moulting season, when feeding was at a minimum or non-existent (Kleivane et al. 1997). However, these authors did not analyse the differences between blubber layers. Sequestration of contaminants to outer blubber layers could occur along lactation. Qualitative variations in lipids between the different layers (polarity) may play a role in the distribution of PCBs in the blubber. At late lactation, the mobilization of less polar triglycerides from blubber could be one explanation of the increased mobilisation of PCBs. It is also possible that, at late lactation, as most of the lipids have disappeared, the retention capacity of the reduced blubber layer for PCBs has reached its maximum. At this stage, PCBs no longer accumulate in the blubber and start to be mobilized in higher amounts at the end of lactation. Fewer transfers, however, seemed to happen in the outer blubber layer than in the inner blubber. This layer thus appeared to be more 'inert' in a physiological sense. Inner blubber reflects the contaminant burden brought via the female's diet during the year. The contaminant burden of this more 'active' layer is more susceptible to have an effect on the metabolism of the animal and to be transferred to offspring.

The increased mobilization of PCBs from blubber at late lactation was coupled to an increase in the levels observed in the serum of mothers. As for milk, the rise seemed to occur at late lactation. Similarly, the dynamics of change of PCBs in milk was accompanied by an increase in the serum of pups, which also occurred at late lactation. The increase of PCB concentrations in the milk ingested at late lactation was even amplified by the increase of daily milk intake at that moment (2.4 $\mathrm{kg}$ at early lactation vs $3 \mathrm{~kg}$ at late lactation, Pomeroy et al. 1996). Indeed, in the study of Pomeroy et al. (1996), the daily PCB exposure of grey seal pups increased during the lactation period. PCBs accumulated exponentially in pup serum compared to maternal serum, as lactation progressed. This phenomenon reflects the increase of PCBs in milk at late lactation coupled with the increase of daily milk intake as lactation progresses. Other factors, such as a better intestinal absorption of lipids at late lactation, may also favour such a relationship. 


\section{CONCLUSION}

Most of the PCB transfer from mother to pup appeared to occur during the latter part of the nursing period. Indeed, contamination levels increased in the different compartments of transfer (maternal inner blubber, maternal serum, milk, pup serum) at late lactation. PCB levels in pup serum increased exponentially compared to those in maternal serum, as lactation progressed. This curious phenomenon poses the question of how a greater maternal investment of some grey seal mothers, with higher body-store mobilization and a longer lactating period, may induce more adverse effects on the nursing pup, as greater amounts of pollutants could then be transferred. At early lactation, blubber layers appeared to have different PCB levels, outer blubber being more contaminated than inner blubber. This variation was much less evident at late lactation, due to the rise of concentrations in the inner blubber layer.

From a molecular point of view, a qualitative study focusing on the composition of the PCB mixture throughout lactation will bring complementary information on the dynamics of transfer of these pollutants from mother to pup in grey seals (Debier et al. 2003, this issue). From a physiological point of view, the distribution of PCBs among lipoproteins in serum, as well as among blubber lipids, should be examined in order to understand the mechanisms of transfer as well as the increase of concentrations observed at late lactation. From an eco-toxicological point of view, body composition changes would allow the calculation of PCB concentrations per unit of body mass and allow a better assessment of the contamination burden of the animals. Total PCB body burden combined with milk output should also enable an estimation of the decontamination rate of individuals per lactation cycle to be made. Finally, from an immuno-toxicological point of view, a study of the survival rate of pups during their first year of life, related to their PCB intake during lactation, should bring answers to the possible adverse impact of PCB exposure during the critical stages of development.

Acknowledgements. Long-term research on the Isle of May is supported by UK NERC's Core Research Programme. Field assistance provided by Simon Moss, Paula Redman, Sean Twiss, Kimberley Bennett, Catriona Stevenson and Susanne McCulloch during the collection of milk and blood samples is gratefully acknowledged. Funding for field work was in part provided by the Belgian National Council for Scientific Research and UK NERC's Core Programme to SMRU. The authors also thank Murielle Louvet and Christine Dykmans from the Laboratoire d'Ecologie animale et d'Ecotoxicologie, University of Liège (Belgium), for valuable help during the chemical analyses and well as Prof. Philippe Baret for helpful comments on the data analyses. C.D. was a research fellow of the Belgian National Council for Scientific Research.

\section{LITERATURE CITED}

Addison RF, Brodie PF (1977) Organochlorine residues in maternal blubber, milk, and pup blubber from grey seals (Halichoerus grypus) from Sable Island, Nova Scotia. J Fish Res Board Can 34:937-941

Addison RF, Brodie PF (1987) Transfer of organochlorine residues from blubber through the circulatory system to milk in the lactating grey seal Halichoerus grypus. Can J Fish Aquat Sci 44:782-786

Addison RF, Stobo WT (2001) Trends in organochlorine residue concentrations and burdens in grey seals (Halichoerus grypus) from Sable Is, NS, Canada, between 1974 and 1994. Environ Pollut 112:505-513

Addison RF, Zinck ME (1986) PCBs have declined more than DDT-group residues in Artic ringed seals (Phoca hispida) between 1972 and 1981. Environ Sci Technol 20:253-256

Aguilar A (1985) Compartmentation and reliability of sampling procedures in organochlorine pollution surveys of cetaceans. Residue Rev 95:91-114

Aguilar A, Borrell A (1994) Abnormally high polychlorinated biphenyl levels in striped dolphins (Stenella coeruleoalba) affected by the 1990-1992 Mediterranean epizootic. Sci Total Environ 154(2-3):237-247

Aguilar A, Borrell B, Pastor T (1999) Biological factors affecting variability of persistent pollutant levels in cetaceans. J Cetacean Res Manag 1:83-116

Bacon CE, Jarman WM, Costa DP (1992) Organochlorine and polychlorinated biphenyl levels in pinniped milk from the Arctic, the Antarctic, California and Australia. Chemosphere 24:779-791

Bang K, Jenssen BM, Lydersen C, Skaare JU (2001) Organochlorine burdens in blood of ringed and bearded seals from north-western Svalbard. Chemosphere 44:193-203

Bard SM (1999) Global transport of anthropogenic contaminants and the consequences for the Artic marine ecosystem. Mar Pollut Bull 38:356-379

Beckmen KB, Lowenstine LJ, Newman J, Hill J, Hanni K, Gerber J (1997) Clinical and pathological characterization of northern elephant seal skin disease. J Wildl Dis 33: 438-449

Beckmen KB, Ylitalo GM, Towell RG, Krahn MM, O'Hara TM, Blake JE (1999) Factors affecting organochlorine contaminant concentrations in milk and blood of northern fur seal (Callorhinus ursinus) dams and pups from St George Island, Alaska. Sci Total Environ 23:183-200

Bernhoft A, Wiig Ø, Skaare JU (1997) Organochlorines in polar bears (Ursus maritimus) at Svalbard. Environ Pollut 95:159-175

Bernhoft A, Skaare JU, Wiig Ø, Derocher A, Larsen HJ (2000) Possible immunotoxic effects of organochlorines in polar bears (Ursus maritimus) at Svalbard. J Toxicol Environ Health 59:561-574

Bernt KE, Hammill MO, Lebeuf M, Kovacs KM (1999) Levels and patterns of PCBs and OC pesticides in harbour and grey seals from the St Lawrence Estuary, Canada. Sci Total Environ 243/244:243-262

Brouwer A, Reijnders PJH, Koeman JH (1989) Polychlorinated biphenyl (PCB)-contaminated fish induces vitamin $A$ and thyroid hormone deficiency in the common seal (Phoca vitulina). Aquat Toxicol 15:99-106

Cleemann M, Riget F, Paulsen GB, de Boer J, Dietz R (2000) Organochlorines in Greenland ringed seals (Phoca hispida). Sci Total Environ 245:103-116

Debier C, Pomeroy PP, Mignolet E, Baret PV, Larondelle Y (2002) Vitamin E status and the dynamics of its transfer between mother and pup in grey seals (Halichoerus gry- 
pus) during lactation. Can J Zool 80:727-737

Debier C, Pomeroy PP, Dupont C, Joiris C, Comblin V, Le Boulengé E, Larondelle Y, Thomé JP (2003) Dynamics of PCB transfer from mother to pup during lactation in UK grey seals Halichoerus grypus: differences in PCB profile between compartments of transfer and changes during the lactation period. Mar Ecol Prog Ser 247:249-256

De Swart RL, Ross PS, Vedder LJ, Timmerman HH and 5 others (1994) Impairment of immune function in harbour seals (Phoca vitulina) feeding on fish from polluted waters. Ambio 23:155-159

Frenich AG, Vidal JL, Frias M, Olea-Serrano F, Olea N (2000) Quantitative determination of endocrine-disrupting polychlorinated biphenyls and organochlorinated pesticides in human serum using gas chromatography with electroncapture detection and tandem mass spectrometry. J Mass Spectrom 35:967-975

Green NJL, Jones KC, Harwood J (1996) Contribution of coplanar and non-coplanar polychlorinated biphenyls to the toxic equivalence of grey seals (Halichoerus grypus) milk. Chemosphere 33:1273-1281

Hammond PS, McConnell BJ, Fedak MA (1993) Grey seals off the east coast of Britain: distribution and movements at sea. Symp Zool Soc Lond 66:211-224

Helle E, Olsson M, Jensen S (1976a) PCB levels correlated with pathological changes in seal uteri. Ambio 5:261-263

Helle E, Olsson M, Jensen S (1976b) DDT and PCB levels and the reproduction in ringed seals from the Bothnian Bay. Ambio 5:188-189

Henderson RJ, Kalogeropoulos N, Alexis MN (1994) The lipid composition of selected tissues from a Mediterranean monk seal, Monachus monachus. Lipids 29:577-582

Janak K, Jensen E, Becher G (1999) Determination of polychlorinated biphenyls in human blood by solid-phase extraction including on-column lipid decomposition. J Chromatogr B 734:219-227

Jenssen BM, Skaare JU, Woldstad S, Nastad AT, Haugen O, Kløven B, Sørmo EG (1995) Biomarkers in blood to assess effects of polychlorinated biphenyls in free-living grey seal pups. In: Blix AS, Walloe L, Ulltang $\varnothing$ (eds) Whales, seals, fish and man. Elsevier Science Publishers, Amsterdam, p 607-615

Jepson PD, Bennett PM, Allchin CR, Law RJ, Kuiken T, Baker JR, Rogan E, Kirkwood JK (1999) Investigating potential associations between chronic exposure to polychlorinated biphenyls and infectious disease mortality in harbour porpoises from England and Wales. Sci Total Environ 243/244:339-348

Kajiwara N, Kannan K, Muraoka M, Watanabe M and 7 others (2001) Organochlorine pesticides, polychlorinated biphenyls, and butyltin compounds in blubber and livers of stranded California sea lions, elephant seals, and harbor seals from coastal California, USA. Arch Environ Contam Toxicol 41:90-99

Kleivane L, Skaare JU, Bjørge A, de Ruiter E, Reijnders PJH (1995) Organochlorine pesticide residue and PCBs in harbour porpoise (Phocoena phocoena) incidentally caught in Scandinavian waters. Environ Pollut 89:137-146

Kleivane L, Espeland O, Fagerheim KA, Hylland K, Polder A, Skaare JU (1997) Organochlorine pesticides and PCBs in the east ice harp seal (Phoca groenlandica) population. Mar Environ Res 43:117-130

Kleivane L, Severinsen T, Skaare JU (2000) Biological transport and mammal to mammal transfer of organochlorines in Artic fauna. Marine Environ Res 49:343-357

Law RJ, Allchin CR, Harwood J (1989) Concentration of organochlorine compounds in the blubber of seals from eastern and north-eastern England, 1988. Mar Pollut Bull 20:110-115

Martineau D, Lagacé A, Béland P, Higgins R, Armstrong D, Shugart LR (1988) Pathology of stranded beluga whales (Delphinapterus leucas) from the St Lawrence estuary, Quebec, Canada. J Comp Path 98:287-310

Mössner S, Ballschmiter K (1997) Marine mammals as global pollution indicators for organochlorines. Chemosphere 34 : 1285-1296

Muir DCG, Wagemann R, Hargrave BT, Thomas D, Peakall DB, Norstrom RJ (1992) Arctic marine ecosystem contamination. Sci Total Environ 122:75-134

Muir DCG, Segstro MD, Hobson KA, Ford CA, Steward REA, Olpinski S (1995) Can seal eating explain elevated levels of PCBs and organochlorine pesticides in walrus blubber from eastern Hudson Bay (Canada)? Environ Pollut 90: $335-348$

Nakata H, Tanabe S, Tatsukawa R, Amano M, Miyazaki N, Petrov EA (1995) Persistent Organochlorine residues and their accumulation kinetics in Baikal seal (Phoca sibirica) from Lake Baikal, Russia. Environ Sci Technol 29: $2877-2885$

Pauwels A, Wells DA, Covaci A, Schepens PJC (1999) Improved sample preparation method for selected persistent organochlorine pollutants in human serum using solidphase disk extraction with gas chromatographic analysis. J Chromatogr B 723:117-125

Pomeroy PP, Green N, Hall AJ, Walton M, Jones K, Harwood J (1996) Congener-specific exposure of grey seal (Halichoerus grypus) pups to chlorinated biphenyls during lactation. Can J Fish Aquat Sci 53:1526-1534

Pomeroy PP, Fedak MA, Rothery P, Anderson SS (1999) Consequences of maternal size for reproductive expenditure and pupping success of grey seals at North Rona, Scotland. J Anim Ecol 68:235-253

Prime JH, Hammond PS (1990) The diet of grey seals from the south-western North Sea assessed from analysis of hard parts found in faeces. J Appl Ecol 27:435-447

Reijnders PJH (1986) Reproductive failure in common seals feeding on fish from polluted coastal waters. Nature 324: $456-457$

Rolland RM (2000) A review of chemically induced alterations in thyroid and vitamin A status from field studies of wildlife and fish. J Wildl Dis 36(4):615-635

Ross PS (2000) Marine mammals as sentinels in ecological risk assessment. Human Ecol Risk Assess 6:29-46

Ross PS, De Swart RL, Reijnders PJH, Van Loveren H, Vos JG, Osterhaus ADME (1995) Contaminant-related suppression of delayed-type hypersensitivity and antibody responses in harbor seals fed herring from the Baltic sea. Environ Health Perpect 103:162-167

Ross PS, De Swart RL, Addison R, Van Loveren H, Vos J, Osterhaus A (1996) Contaminant-induced immunotoxicity in harbour seals: wildlife at risk? Toxicology 112:157-169

SAS/STAT (1990) User's guide, Vol 2. GLM-VARCOMP Version 6, 4th edn. SAS Institute, Cary, NC

Schweigert FJ, Stobo WT (1994) Transfer of fat-soluble vitamins and PCBs from mother to pups in grey seals (Halichoerus grypus). Comp Biochem Physiol 109C:111-117

Severinsen T, Skaare JU, Lydersen C (2000) Spatial distribution of persistent organochlorines in ringed seal (Phoca hispida) blubber. Mar Environ Res 49:291-302

Simms W, Jeffries S, Ikonomou M, Ross PS (2000) Contaminant-related disruption of vitamin A dynamics in freeranging harbor seal (Phoca vitulina) pups from British Columbia, Canada, and Washington State, USA. Environ Toxicol Chem 19(11):2844-2849 
Singh AK, Spassova D, White T (1998) Quantitative analysis of polychlorinated biphenyls, organochlorine insecticides, polycyclic aromatic hydrocarbons, polychlorinated hydrocarbons and polynitrohydrocarbons in spiked samples of soil water and plasma by selected-ion monitoring gas chromatography-mass spectrometry. J Chromatogr B 706: 231-244

Skaare JU, Markussen NH, Norheim G, Haugen S, Holt G (1990) Levels of polychlorinated biphenyls, organochlorine pesticides, mercury, cadmium, copper, selenium, arsenic, and zinc in harbour seal, Phoca vitulina, in Norwegian waters. Environ Pollut 66:309-324

Tanabe S, Tatsukawa R, Tanaka H, Maruyama K, Miyazaki N, Fujiyama T (1981) Distribution and total burdens of chlorinated hydrocarbons in bodies of striped dolphins (Stenella coeruleoalba). Agric Biol Chem 45(11):2569-2578

Tanabe S, Sung JK, Choi DY, Baba N, Kiyota M, Yoshida K, Tatsukawa R (1994) Persistent organochlorine residues in Northern fur seal from the Pacific coast of Japan since 1971. Environ Pollut 85:305-314

Editorial responsibility: Otto Kinne (Editor), Oldendorf/Luhe, Germany
Timbrell JA (1991) Principles of biochemical toxicology. Taylor \& Francis, London

Troisi GM, Mason CF (2000) PCB-associated alteration of hepatic steroid metabolism in Harbour Seals (Phoca vitulina). J Toxicol Environ Health Part A 61:649-655

Westgate AJ, Muir DCG, Gaskin DE, Kingsley MCS (1997) Concentrations and accumulation patterns of organochlorine contaminants in blubber of harbour porpoises, Phocoena phocoena, from the coast of Newfoundland, the Gulf of St Lawrence and the Bay of Fundy/Gulf of Maine. Environ Pollut 95:105-119

Wolkers J, Burkow IC, Lydersen C, Dahle S, Monshouwer M, Witkamp RF (1998) Congener specific PCB and polychlorinated camphene (toxaphene) levels in Svalbard ringed seals (Phoca hispida) in relation to sex, age, condition and cytochrone P450 enzyme activity. Sci Total Environ 216: $1-11$

Zakharov VM, Yablokov AV (1990) Skull asymmetry in Baltic Grey Seal: effects of environmental pollution. Ambio 19: 266-269

Submitted: February 22, 2002; Accepted: November 19, 2002 Proofs received from author(s): January 16, 2003 